\title{
The Productivity Race: British Manufacturing in Historical Perspective, 1850-1990
}

\author{
lan Clark
}

Stephen Broadberry, The Productivity Race: British Manufacturing in International Perspective, 1850-1990 (Cambridge University Press: 1997) 451pp., £45.00, ISBN 0-521-58440.

The role of the industrial relations system in the post-war decline of the British economy, and its manufacturing sector in particular, appears to be clear-cut and incontrovertible. Craft-dominated trade unions controlled the shop-floor and prevented management from introducing improved methods of work organization and reforming industrial relations. In the absence of productivity bargaining, the performance of British manufacturers suffered in comparison with the United States and European economies. By the 1970s British economic performance relative to the early post-war period was unfavourable to poor.

Stephen Broadberry's book, although a major work of empirical econometric research, presents this qualitative matter-of-fact conclusion on industrial relations with only perfunctory reference to historical material. This weakness casts doubt on Broadberry's overall assertions on trade unions and industrial relations, which appear to draw firm conclusions about the British industrial relations system without sustained engagement with, or even reference to, the available literature. Industrial relations scholarship has failed to engage with and dispute this type of approach. ${ }^{1}$ This review essay attempts to counter both tendencies. It divides into four sections: (1) the main arguments of

1. I have made this point in a wider historical context: I. Clark, 'Institutional Stability in Management Practice and Industrial Relations: The Influence of the Anglo-American Council for Productivity, 1948-1952', Business History 41:3 (1999), pp. 64-93. 
Broadberry's book; (2) an examination of its research base and its wider framework; (3) the book's central arguments and how other authors address the topic; (4) an examination of the characterization of production and productivity during the early post-war and the contemporary periods.

\section{The book's main arguments}

The Productivity Race contains four core arguments that run through each section of the book. First, the period since 1850 has witnessed a substantial comparative decline in Britain's overall labour productivity in the manufacturing sector, yet Britain's comparative level of labour productivity appears stationary (pp. 1, 395). Labour productivity in American manufacturing is twice the British level, whereas productivity in the British and German manufacturing sectors show a broad equality over the whole period. However, while the UK pulled ahead in the early post-war period, West Germany gained over the UK in the 1970s. The contemporary period since 1979 saw free-market reforms in the labour market and in industrial relations once again increase British levels of labour productivity in the manufacturing sector in comparison with Germany. The blame for Britain's relative economic decline therefore lies beyond the performance of the manufacturing sector. Trends in other sectors of the economy and the effects of structural change appear, if only by assertion, of greater significance than the performance of the manufacturing sector.

The second core argument addresses the UK's persistent manufacturing sector productivity gap with the United States. Three interrelated factors substantiate the case. Throughout the post-war period until 1979, British attempts to introduce American mass- or volumeproduction methods were on the whole unsuccessful. ${ }^{2}$ A major factor in this failure was the presence of well-organized craft labour that was controlled and mobilized by lay activists at the point of production.

2. Broadberry uses this term throughout the book. However, the notion of mass production is a matter of debate. For example, Clark demonstrates that for British manufacturers in the immediate post-war years the focus of American 'best practice' was standardization and simplification, not necessarily mass production: Clark 'Institutional Stability in Management Practice and Industrial Relations', Bus. Hist.. Equally, Lyddon argues that the term 'mass production' is misleading, suggesting that the phrase refers to the scale of production rather than its process; that is, mass production does not necessarily rely on or require specialist man- 
Trade unions either frustrated attempts by management to introduce standardized volume-production or prevented management from considering it. Here, the role of workplace restrictive practices appears particularly significant. Even when the state, employers and managers had an opportunity to reform the structure of manufacturing industry and its associated patterns of industrial relations, each erred on the side of caution. However, trade-union resistance to change appears as the significant factor (pp. 398-9).

The third core argument suggests that, while the failure to introduce standardized volume-production during the post-war period explains Britain's manufacturing productivity gap in comparison with the United States, the movement to that basis for manufacturing was not at that time viable (pp. 13, 396). The UK emerged from the Second World War in 1945 dependent on diverse Empire markets that accounted for approximately $50 \%$ of its exports until the early 1970s. This aspect to the overall argument appears peculiarly Kaldorian, particularly if one bears in mind the second core argument that highlights the role of trade unions in Britain's failure to move to volumeproduction systems in manufacturing.

Nicholas Kaldor's explanation of the UK's comparatively poor economic performance over the post-war period is authoritative because of its recognition of non-economic factors; it remains significant today. ${ }^{3}$ Kaldor demonstrates convincingly that because post-war macro-economic management secured full employment very quickly, successive governments felt no need to change the institutional framework in industrial relations. ${ }^{4}$ For example, governments recognized the utility of continuing with existing patterns of joint regulation between employers and organized labour as laid out in the 1944 White Paper on full employment. ${ }^{5}$ Kaldor further argues that the then current pattern of domestic economic management, later termed 'stop-go',

agement techniques, and hence the term 'volume production' appears more appropriate: D. Lyddon 'The Myth of Mass Production and the Mass Production of Myth', Historical Studies in Industrial Relations 1 (March 1996), pp. 77-105.

3. N. Kaldor, The Causes of the Slow Rate of Economic Growth in The United Kingdom (Cambridge University Press: 1966); idem, 'Conflicts in National Economic Objectives', Economic Journal (EJ) 81:1 (1971), pp. 1-16; idem, 'Capitalism and Industrial Development: Some Lessons from Britain's Experience', Cambridge Journal of Economics 1 (1977), pp. 193-204.

4. Kaldor, 'Conflicts in National Economic Objectives', EJ, p. 3.

5. Ibid. 
succeeded because it aimed to mitigate rather than overcome the longterm adverse trend in the UK's international competitiveness. ${ }^{6}$ Institutional and political factors, such as Britain's industrial relations system, had only marginal impact upon post-war economic decline. In the wider context of the post-war aims and objectives of the British state, economic performance could not have been better than it was. ${ }^{7}$ For Broadberry, the UK's post-war productivity gap in manufacturing resulted from a failure to introduce American methods of production. However, the evidence suggests that diverse British markets at home and abroad appeared ill-suited to volume production, as well as craft trade unions finding unacceptable the potential de-skilling associated with volume production.

The difference between Kaldor and Broadberry revolves around the issue of industrial relations. Kaldor concludes that state policy on exchange rates, international relations, the sterling area and Imperial export markets imposed significant constraints on the domestic economy and that, in this wider context, post-war economic performance was very good relative to the recent past. This conclusion suggests two points that limit Broadberry's broad-brush assertions on industrial relations. First, post-war economic management, particularly the constraining effects of stop-go policies, aimed to maintain Britain's wider role in the international political economy. Second, Imperial markets appeared ill-suited to standardized volume goods on the American model. Hence, with continuity in markets and methods of production, one marginal factor such as industrial relations could not inhibit economic performance measured in the wider context. In contrast, Broadberry suggests that workplace industrial relations represent a key factor in the deterioration of post-war economic performance.

In order to explain Broadberry's position on trade unions, and in particular why they appear more significant than other institutional and political factors identified by Kaldor, it is necessary to turn to the fourth argument in The Productivity Race. The overall performance of the British economy has been disappointing since 1945, yet poor performance in manufacturing appears confined to the period 1950-79 (pp. 397-8). The years 1979 to 1990 saw Conservative governments, committed to the ideology of the market and the reform of workplace industrial relations, reverse the process of comparative economic decline. New systems of manufacturing technology created more

6. Ibid., p. 15.

7. Ibid. 
flexible production methods with an emphasis on customization and skilled labour.

The connection between the third and fourth core arguments of The Productivity Race centres on the alleged presence of mistaken economic policies during the post-war years that undermined comparative economic performance until the 1980s. The state maintained and managed a deficient institutional structure where slow growth markets had the effect of subsidizing physical capital; state ownership was widespread but inefficient; and voluntary reform of the industrial relations system was a failure (pp. 13-16, 398). These factors combined to provide poor vocational training, while industrial relations practices created unemployment. Thus the wider institutional structure that surrounded the manufacturing sector limited its economic performance. It was not until changes in the bargaining environment and associated developments in industrial relations during the 1980s that the UK's productivity gap with other European states decreased. In summary, until the 1980s the state effectively failed to support employer strategies associated with volume production and failed to recognize that Imperial markets could not sustain competitive growth in labour productivity in the manufacturing sector. In particular, the final core argument asserts that successive post-war governments allowed restrictive and obsolete patterns of industrial relations to undermine the potential for volume production in much of the manufacturing sector.

Recognition of this failure became clear only when Conservative governments reformed industrial relations, restricting the impact of multi-unionism and associated restrictive practices. The market values and assumptions of Austrian economics, dominant in the UK since the 1980s, have presented institutions such as trade unions and processes such as collective bargaining as distortions of the market mechanism that can only damage economic performance. ${ }^{8}$ The view mobilizes an ideological campaign designed to isolate the post-war industrial relations system as the primary cause of economic decline in the period until 1979. More critically, the assertion appears fragile in terms of historical method, for it revises or ignores much of the established quali-

8. For a critical account of Hayek's attacks on employment and trade union rights, see Lord Wedderburn, Employment Rights in Britain and Europe (Lawrence and Wishart: 1991), chapter 8, 'Freedom of Association and Philosophies of Labour Law: The Thatcher Ideology'. For an analysis of Hayek's 'new right' theory of the state, see P. Dunleavy and B. O'Leary, Theories of the State (Macmillan: 1987). For a sympathetic treatment of Hayek, see J. Tomlinson, Hayek and the Market (Pluto: 1990). 
tative literature and documents as 'revisionist' and 'unconvincing' archive-led accounts. ${ }^{9}$

\section{The research base and its wider framework}

The research detailed in The Productivity Race is a re-examination of the performance of the British manufacturing sector since 1850 using a framework of technological evolution over three periods, 1850-1914, 1914-50 and 1950-90. Part one of the book establishes the long-term pattern and trend of productivity in the American, British and German manufacturing sectors. Part two explains these patterns of productivity, highlighting the parallel development of volume-production and flexible-production techniques. For Broadberry, standardization and customization in output and associated skill levels in the labour force appear as key analytical factors, explaining the superior efficiency of American volume-production techniques. To establish how British manufacturers failed to introduce such techniques, part two of the book assesses the role played by technology, markets, investment in human and physical capital, and competition. Apparently, unlike their German counterparts, British manufacturers failed to sustain flexible patterns of production or a highly skilled labour force. Part three turns to a detailed evaluation of productivity in all branches of manufacturing.

The three historical periods each receive a prefix - 'the rise-of-competition from abroad', 'war and depression' and 'changing markets and technologies' - and while the four core arguments flow through each part of the book they are particularly telling in the last. In summary, Broadberry's framework leads to a reassessment of the performance of British industry that posts the following factors as significant explanations of Britain's relative economic decline. First, in the period to 1914 British performance did not so much decline as did US and German performance accelerate. Second, in the period to 1950, world wars punctuated by depression pushed Britain into a pattern of industrial production and international trade dominated by Imperial markets that eschewed standardized volume production. Third, between 1950

9. Broadberry, in his work jointly published with Nick Crafts, has previously aired this view and been subject to criticism from Clark in 'Institutional Stability in Management Practice and Industrial Relations', Bus. Hist., J. Tomlinson and N. Tiratsoo, 'An Old Story Freshly Told? A Comment on Broadberry and Crafts' Approach to Britain's Early PostWar Economic Performance', Bus. Hist. 40:2 (1998), pp. 62-72. 
and 1990 Britain found itself servicing comparatively low-value, lowproductivity export markets with cumulatively deficient levels of plant, equipment and technology.

The research base and framework offer detailed productivity measurements combined with qualitative industrial and business history. However, the significance of this approach is not so much its authority or its credibility but the manner by which its conclusions undermine the work of industrial relations scholars and those from other disciplines with an interest in industrial relations. This is because what appears to emerge from each core argument are the corrosive and sclerotic effects of the industrial relations system on Britain's post-war economic performance. This argument appears credible and is significant precisely because it contains too little qualitative industrial and business history and virtually no analysis of the industrial relations system.

The industrial relations system and the failure of 'American' volume production

In many respects the generality of three of the core arguments in The Productivity Race appears persuasive. Over the long run, Britain's productivity performance in comparison with the United States and Germany is poor; equally, in the post-war period, Britain held neither the appropriate markets nor an inclination to manage a strategic introduction of volume-production systems into the manufacturing sector. However, the final core argument is historically flawed and appears to contradict the first core argument.

Broadberry asserts that whereas the comparative performance of the British economy did indeed disappoint during the period from 1950, its performance since 1979 represents a significant improvement. Moreover, reform of the industrial relations system represents the major factor in this process. The power of trade unions and the failings of the economy resulted from mistaken economic policies that undermined the UK's long-run economic performance. The presentation of chance and mistake as explanations for historical causation has a long pedigree. However, as plausible historical method they are insignificant.

E. H. Carr demonstrates that chance and mistakes are unconvincing for two reasons..$^{10}$ First, the notions of accident, chance or mistake

10. E. H. Carr, What is History? (Penguin, Harmondsworth: 1987), chapters 4 and 5. 
imply a counterfactual interpretation of history - arguments and conclusions that run counter to a generally agreed position. ${ }^{11}$ A particular methodological problem encountered by counterfactual approaches is a reliance on hypothetical arguments that pose alternative courses of action based on negatives; for example, what would the situation have been if Americanized systems of volume production had been introduced by British firms in the post-war period? Broadberry suggests that if the UK had moved to US volume- or flexible-production systems, post-war economic performance might have been better than it was. ${ }^{12}$ In large measure, improved performance would follow on from better management systems for work organization and workplace industrial relations. The second and related reason why the notions are unconvincing relates to causation. To governments, employers and, in all likelihood, trade unions, past decisions that now appear as mistakes, accidents or the result of chance are not necessarily so. Such decisions may result in unfavourable consequences, yet an alternative course of action could not and did not prevail because alternative courses require alternative patterns of causation. That is, it is impossible to conclude with any authority that Britain's post-war economic performance was held back by a failure to adopt volume- or more flexible-production systems. The issue of causation reprises the authority of Kaldor's approach. Kaldor establishes that post-war economic policy, including that on industrial relations, was not mistaken, the result of chance or an accident. In contrast to these potentially counterfactual possibilities, Kaldor's formulation on post-war economic and industrial relations policy describes not the ideal that economists prefer but the situation that actually prevailed. ${ }^{13}$

11. For example, Alan Milward argues that the failure of the Marshall plan proves that it was not necessary to maintain the UK's post-war output boom prior to 1947. Milward suggests that the Marshall plan did indeed help to maintain the boom but without it the British government would have found an alternative way to avoid a post-war recession: A. Milward, 'Was the Marshall Plan Necessary?' Diplomatic History 13:2 (1989), pp. 231-53; idem, The Reconstruction of Western Europe 1945-1951 (Routledge: 1984).

12. This case has been put forward by C. Barnett, The Lost Victory: British Dreams, British Reality, 1945-1950 (Macmillan: 1995). Barnett's argument has been subject to sustained criticism; see Clark, 'Institutional Stability in Management Practice and Industrial Relations', Bus. Hist., and J. Tomlinson, 'Corelli Barnett's History: The Case of Marshall Aid', Twentieth Century History 8 (1997), pp. 222-38.

13. Kaldor, 'Conflicts in National Economic Objectives', EJ, pp. 14-16. 
The counterfactual element in Broadberry's argument is also retrospective in its promotion of free-market values. In this respect one arrives at the conclusion that mistaken post-war policies on the economy and the industrial relations system only appeared so in the context of a future alternative direction for policy - one that 'meant an end to the terrible industrial relations disputes of the 1960s and 1970s' (p. 398). To argue that if volume-production systems in the post-war period were only partially implemented then industrial relations might not have been so problematic indicates only a loose grasp of historical method. Equally, it is difficult to prove one, let alone two, negatives. Moreover, as Carr further demonstrates, a particular event will commonly have several causes - economic, political, ideological, shortterm and long-term. ${ }^{14}$ To paraphrase Carr, merely stating that the Second World War started because Hitler wanted war is true enough, but explains nothing. ${ }^{15}$ The same argument applies to industrial relations: stating that poor industrial relations caused Britain's economic decline in the post-war period may be true but it explains nothing. Industrial relations appear as a proximate explanation, one that requires further explanation within other short-term and longterm causes.

A further problem for industrial relations specialists who focus on the historical or the contemporary is the significance that proximate explanations appear to hold within atypical and non-historical agendas that are dominated by managerial and prescriptive interests. For example, Richard Hyman notes that until recently any text on British industrial relations would emphasize the importance of history, in particular the trinity of industrial relations traditions: voluntarism, free collective bargaining by trade unions, and unscientific management by employers. ${ }^{16}$ The erosion of this framework has been followed by the reconstruction of management as human resource management. This generalizes a set of research priorities that promote the economic and political interests of employers and the state and that exclude consideration of employee interests, defined either collectively or individually. ${ }^{17}$ A discussion of Broadberry's four core arguments through the filter of more qualitative and less econometric literature may counterbalance

14. Carr, What is History?, p. 89.

15. Ibid., p. 87.

16. R. Hyman, 'The Historical Evolution of British Industrial Relations', in P. Edwards (ed.), Industrial Relations (Blackwell, Oxford: 1995).

17. J. Kelly, Rethinking Industrial Relations: Mobilization, Collectivism and Long Waves (Routledge: 1998), chapter 2. 
the priority and significance attached to the role of industrial relations in post-war decline.

Corelli Barnett argues that Britain failed to restructure its manufacturing sector in the immediate post-war period because of the state's obsession with 'great power' status and its fear of trade-union resistance. ${ }^{18}$ Hence the Attlee government wasted Marshall aid on debt retirement to maintain the sterling area instead of restructuring the manufacturing sector into larger integrated units, while gradually removing wartime controls on the industrial relations system. The latter set the train of voluntary patterns for job regulation and dispute resolution that remained until the Conservative reforms of the early 1980s. Barnett's approach appears convincing, but it isolates the apparent strength of the organized working class to resist change from the actual disinterest that employers and managers had in American systems for volume production. This is particularly the case in Barnett's treatment of the early post-war years, when the weight of evidence indicates that employers and the state were preoccupied with security of product markets rather than product innovation. ${ }^{19}$

Anthony Carew provides a more fruitful, if controversial, explanation for the failure to introduce American production techniques in the UK. ${ }^{20} \mathrm{He}$ demonstrates that the significance of scientific management lay not necessarily in its practice but in its propaganda value during the Cold War. Marshall aid and associated businessmen's programmes during the 1950s had one aim and one lasting achievement. By the 1960s the programmes had finalized a split in the international labour movement to reinforce the anti-Communism in much of European labour. Over the medium term, the late 1960s saw the emergence of workplace productivity bargaining (a central element of job regulation in American volume production) as the key theme in the reform of British industrial relations. More significantly, Carew asserts that Allan Flanders was an early convert to the merits of productivity bargaining in the early 1950s during his editorship of Socialist Commentary.

18. Barnett, The Lost Victory; see also C. Barnett, The Audit of War: The Illusion and Reality of Britain as a Great Nation (Macmillan: 1986).

19. Clark, 'Institutional Stability in Management Practice and Industrial Relations', Bus. Hist.; Tomlinson, 'Corelli Barnett's History', Twentieth Cent. Hist.

20. A. Carew, Labour under the Marshall Plan: The Politics of Productivity and the Marketing of Management Science (Manchester University Press: 1987). 
In summary, Carew argues that the failure of scientific management in the early post-war period was less significant than its role in mobilizing the labour movement against Communism. Of greater importance, the comparative failure of productivity bargaining in British industrial relations illustrates one effect of inappropriate production systems, size of markets, and employer and management interests. In this respect Broadberry echoes two of Carew's conclusions, but the latter's third conclusion, on employer short-termism, is equally significant as it moves the debate beyond trade unions and collective bargaining.

A further perspective on the failure of American volume-production techniques in the post-war period demonstrates that the state and employers had little interest in the economic and institutional restructuring necessary to sustain them. ${ }^{21}$ Documentary sources illustrate quite clearly the opposition of British employers to standardization in production on three counts. First, the British manufacturing sector did not serve a large standardized market; on the contrary, British manufacturers served highly differentiated domestic and export markets. Second, many British firms were small in comparison with their US counterparts, serving localized markets or niche export markets; for example, in the late $1940 \mathrm{~s} 70 \%$ of the UK labour force in the manufacturing sector worked in units employing fewer than 500 workers. ${ }^{22}$ The evidence suggests that diversity of end-user requirements was considerable. The Federation of British Industry (FBI) cited examples of steel manufacturing, metal window frames, gear-cutting equipment and cooker hobs. ${ }^{23}$ To standardize output would require amalgamations and mergers plus significant investment in new plant, machinery and assembly-line systems. Many companies argued that these measures were inappropriate and too expensive to consider - a course of action that was likely to lose already established markets rather than to help to improve market share. ${ }^{24}$ Furthermore, as Keith Middlemas points out, many firms had price-fixing and cartel arrangements in Imperial

21. Clark, 'Institutional Stability in Management Practice and Industrial Relations', Bus. Hist., pp. 71-9.

22. 'Size of UK Manufacturing Plants, October 1948', Anglo-American Council for Productivity (AACP)/Federation of British Industry (FBI) papers, MSS 200 F/3T/328/1, Modern Records Centre, University of Warwick (MRC).

23. 'Industrial Standardization in the UK', AACP/FBI papers, MSS 200 F/3T/328/1, MRC.

24. Ibid.; see also Clark, 'Institutional Stability in Management Practice and Industrial Relations', Bus. Hist. 
markets, deemed a situation preferable to competing in the US market or the emerging western European market in the 1950s. ${ }^{25}$

Third, evidence for the early post-war period suggests that many employers saw US-inspired volume production as a threat to traditional management styles. For example, the demonstration of statistical and quantitative methods to British representatives on AngloAmerican Council for Productivity study trips to the United States found many British representatives poorly prepared. In some sectors of manufacturing industry, systems for work organization, pay systems and job allocation appeared so informal that the calculation of productivity levels, unit costs and manning levels proved almost impossible. ${ }^{26}$ In general, employers appeared to prefer craft methods of manufacturing as opposed to 'scientific' systems, because they were efficient enough for the markets that British firms supplied. Equally, craft methods, regulated as they were by national agreement, kept the negotiation of industrial relations matters outside the workplace. The evidence suggests that the FBI and many managers also feared that a movement to workplace industrial relations would erode management control. ${ }^{27}$

In the post-war period, especially during the 1950s, the FBI and the Trades Union Congress both lobbied for free collective bargaining implemented through national agreements. This appeared to be the appropriate course of action for companies because of the continuity with the inter-war period in markets, management and work organization. Such continuity allowed for stability in patterns of job regulation, including workplace restrictive practices. ${ }^{28}$ In some sectors, notably engineering, companies preferred national agreements that they could then use to undermine union activism in the workplace. ${ }^{29}$ For many companies this position represented one of the major post-war miscalculations by British management, which in part contributed to the emergence of the informal system of industrial relations during the 1960s. However, this pattern of industrial relations followed from

25. K. Middlemas, Power, Competition and the State, Vol. 1 (Macmillan: 1986).

26. See AACP, Productivity Team Report for Iron and Steel (AACP: 1952), p. 13.

27. Clark, 'Institutional Stability in Management Practice and Industrial Relations', Bus. Hist., p. 78.

28. Ibid., pp. 77-9. For historical material, see F. Zweig, Productivity and Trade Unions (Blackwell, Oxford: 1951).

29. J. Hinton, Shop Floor Citizens: Engineering Democracy in 1940s Britain (Edward Elgar, Cheltenham: 1994). 
employer decisions, the primary motivation for which lay beyond the intransigence of trade unions and collective bargaining.

Employer decisions were not necessarily mistaken; instead, the approach of management may have been necessary but consequential in the wider economic and political context of state policy. The key issue is tracing the route of causation for the pattern of industrial relations in the 1960s and 1970s. Trade-union intransigence and restrictive practices did not necessarily cause this, but both resistance strategies were responses to the use of established systems of work organization and associated patterns of industrial relations in very tight post-war economic conditions. For example, in the late 1960s both Graham Reid and H. A. Turner argued that a central difficulty for industrial relations reform was the presence of disorderly pay structures and informal systems of workplace industrial relations that appeared of marginal significance to employers and managers in the conditions of post-war economic boom. ${ }^{30} \mathrm{~A}$ movement to volume standardization in production and a pattern of productivity bargaining regulated in the workplace appeared as a low priority for the state for two reasons. First, non-standard markets in the sterling Imperial area represented at least $50 \%$ of the UK's total export market. In the shortto-medium term these markets were irreplaceable. Second, the UK was a manufacturing economy that exported goods in return for imports of food and raw materials. Allied to the determination of successive postwar governments to sustain sterling as a reserve currency, this legitimized a post-war output drive sustained by extensive means considerable overtime working in conjunction with comparatively low investment. The output drive had a considerable impact on labour productivity and the labour market. Full employment worked in combination with employer preference for national agreements to create resultant pressures in the industrial relations system.

For Broadberry, the comparative failure of volume production in the UK during the post-war period is self-evident. However, for employers and, more significantly, the state, this was not necessarily the case. Equally, 'the failure' did indeed result in consequences for industrial relations but trade-union policies reflected those of the state and employers. As Broadberry observes (in his third core argument) the movement to US volume production was not viable; but, on the basis of the argument offered here and elsewhere, the viability of the decision

30. G. Reid, 'An Economic Comment on the Donovan Report', British Journal of Industrial Relations 6:3 (1968), pp. 303-15; H. A. Turner, 'The Donovan Report', EJ 79:1 (1969), pp. 1-10. 
did not turn on the power and intransigence of trade unions. ${ }^{31}$ Equally, in the contemporary period since 1979 the weight of empirical evidence suggests that the comparative performance of the British economy has failed to improve, while the industrial relations system is now subject to significant legal regulation. ${ }^{32}$

\section{Productivity in the period since 1945}

As The Productivity Race demonstrates, in the early post-war years the UK emerged with a considerable productivity lead over its mainland European competitors. But the UK's comparative performance had begun to deteriorate by the 1960 s. In the early 1980 s the comparative performance of the UK manufacturing sector surged ahead of European competitors; yet, as Broadberry's concluding chapter concedes, industrial output collapsed during the period 1989-92 and had not recovered by the late 1990s. Hence it appears that, relative to the early post-war period, and comparatively in relation to European competitors, the British economy - particularly its manufacturing sectors - remains in third place behind the United States and Germany in the productivity race.

In the context of the wider aims and objectives of the state and employers in the post-war period, industrial relations appears as one factor that affected the performance of the British economy. In the contemporary period the reform of industrial relations has made little difference to the UK's long-term trend in comparative economic performance. Broadberry's book argues that the failure to introduce American production techniques is central to the UK's productivity gap with the United States and its comparative decline against the German economy. However, the assertion that trade unions and collective bargaining represent significant factors for employer and state reticence in this area is not proven.

Department of Human Resource Management De Montfort University,

Leceister LE1 9BH

31. I. Clark, Governance, Regulation, the State and Industrial Relations (Routledge: 2000).

32. P. Nolan, 'Walking on Water: Performance and Industrial Relations under Thatcher', Industrial Relations Journal 20:2 (1989), pp. 81-92; N. Crafts The Conservative Government's Economic Record: An End of Term Report (IEA: 1998). 